\title{
PENGARUH ROA, NPM, EPS TERHADAP RETURN SAHAM PADA EMITEN JAKARTA ISLAMIC INDEX TAHUN 2010-20131]
}

\author{
Rianti Syahputri \\ Mahasiswa Program Studi S1 Ekonomi Islam - Fakultas Ekonommi dan Bisnis - Universitas \\ Airlangga \\ Email: rianti2905@gmail.com \\ Leo Herlambang \\ Departemen Ekonomi Syariah - Fakultas Ekonomi dan Bisnis - Universitas Airlangga \\ Email: leo.herlambang@gmail.com
}

\begin{abstract}
:
The purpose of this research is to investigate the significant effect of the variables Return On Asset and Net Profit Margin as well as the Earning Per Share partially and simultaneously to the stock return of sharia stock that were listed on Jakarta Islamic Index period 2010-2013. The approach that is used is the quantitative approach using regression analysis the data panel with four variables return on asset, net profit margin and earning per share as exogenous variable and stock return as endogenous variable. The companies that are used for this research are Astra Agro Lestari Tbk, Astra Internasional Tbk, Alam Sutera Realty Tbk, Charoen Pokphand Indonesia Tbk, Indocement Tunggal Prakarsa Tbk, Indo Tambangraya Megah Tbk, Kalbe Farma Tbk, Lippo Karawaci Tbk, PP London Sumatra Indonesia Tbk, Tambang Batubara Bukit Asam (Persero) Tbk, Semen Indonesia (Persero) Tbk, Telekomunikasi Indonesia (Persero) Tbk, United Tractors Tbk, Unilever Indonesia Tbk. The data that is used is a secondary data. All data are gathered from the annual financial report of the period 2010-2013.
\end{abstract}

Keywords: profitability ratio, return on asset, net profit margin, earning per share, stock return.

\section{PENDAHULUAN}

Pasar modal adalah salah satu alternatif yang dapat dimanfaatkan perusahaan untuk memenuhi kebutuhan dananya. Jasa-jasa perbankan memang lebih dahulu dalam membangun perekonomian negara. Sejalan dengan eksistensi yang telah diakui dan dimanfaatkan oleh masyarakat maupun pemerintah, dana perbankan tumbuh meningkat dalam setiap tahun. Baik perbankan maupun pasar modal, keduanya adalah lembaga-lembaga yang bahu membahu. Di negara yang telah mapan, kedua lembaga ini sangat diperlukan kehadirannya dalam mejalankan peranan memobilitas dana untuk pembangunan. Karena itu negara yang telah berkembang mengusahakan kehadiran pasar modal (Anoraga dan Pakarti 2008:2).

Jakarta Islamic Index (JII), yang merupakan benchmark saham syariah di Indonesia terdiri dari 30 saham yang diseleksi oleh Dewan Syariah Nasional (DSN) per semester, tepatnya setiap bulan Mei dan November. Keberadaan kelompok saham-saham syariah dalam Jakarta Islamic Index (JII) relatif masih baru, tetapi dari tahun ke tahun index saham syariah dalam kelompok Jakarta Islamic Index (JII) menunjukan nilai yang terus naik. Sebagai

1) Jurnal ini merupakan bagian dari skripsi yang ditulis oleh Rianti Syahputri, NIM : 041110475 , yang diuji pada 06 Februari 2015 
gambaran nilai index saham syariah dalam Jakarta Islamic Index (JII) untuk tahun 2010 hingga 2013 nampak seperti dalam tabel berikut :

Tabel 1.

Kinerja Index Saham Syariah Dalam JII Tahun 2010-2013

\begin{tabular}{|l|l|c|c|c|}
\hline No & Tahun & $\begin{array}{c}\text { Index } \\
\text { JII }\end{array}$ & $\begin{array}{c}\text { Kapitalisasi } \\
\text { Pasar JII }\end{array}$ & \% \\
\hline 1. & 2010 & 532,90 & $1,134632.00$ & 34.94 \\
\hline 2. & 2011 & 537,03 & $1,414,983.81$ & 40.00 \\
\hline 3. & 2012 & 594,79 & $1,671,004.24$ & 40.49 \\
\hline 4. & 2013 & 585,11 & $1,672,099,91$ & 39,63 \\
\hline
\end{tabular}

Sumber : www.ojk.go.id

Analisis fundamental adalah analisis memperkirakan harga saham di masa yang akan datang dengan mengestimasi nilai faktor-faktor fundamental yang mempengaruhi harga saham di masa yang akan datang dan menerapkan hubungan variabel-variabel tersebut sehingga diperoleh taksiran harga saham (Husnan, 2003:303). Laporan keuangan merupakan sebuah informasi yang penting bagi investor dalam mengambil keputusan investasi. Manfaat laporan keuangan tersebut menjadi optimal bagi investor apabila investor dapat menganalisis lebih lanjut melalui analisis rasio keuangan (Penman, 1991). Pengembangan penelitian terdahulu tentang faktor-faktor yang mempengaruhi return saham dapat dikembangkan untuk saham syariah dalam Jakarta Islamic Index (JII) dan penelitian ini akan menganalisis tentang pengaruh rasio profitabilitas terhadap return saham syariah dalam Jakarta Islamic Index (JII).

\section{Perumusan Masalah}

a. Apakah Return On Assets (ROA) mempunyai pengaruh signifikan secara parsial terhadap return saham pada emiten Jakarta Islamic Index tahun 2010 2013?

b. Apakah Net Profit Margin (NPM) mempunyai pengaruh signifikan secara parsial terhadap return saham pada emiten Jakarta Islamic Index tahun 2010 2013 ?

c. Apakah Earning Per Share (EPS) mempunyai pengaruh signifikan secara parsial terhadap return saham pada emiten Jakarta Islamic Index tahun 2010 2013 ?

d. Apakah Return On Asset (ROA), Net Profit Margin (NPM) dan Earning Per Share (EPS) mempunyai pengaruh signifikan secara simultan terhadap return saham pada emiten Jakarta Islamic Index tahun $2010-2013$ ?

\section{Tujuan Penelitian}

Tujuan yang ingin dicapai dari penelitian ini adalah:

a. Mengetahui seberapa besar pengaruh signifikan Return On Assets (ROA) secara parsial terhadap return saham pada emiten Jakarta Islamic Index tahun 2010 $-2013$.

b. Mengetahui seberapa besar pengaruh signifikan Net Profit Margin (NPM) secara parsial terhadap return saham pada emiten Jakarta Islamic Index tahun 2010 $-2013$. 
c. Mengetahui seberapa besar pengaruh signifikan Earning Per Share (EPS) secara parsial terhadap return saham pada emiten Jakarta Islamic Index tahun 2010 $-2013$.

d. Mengetahui seberapa besar pengaruh signifikan Return On Asset (ROA), Net Profit Margin (NPM) dan Earning Per Share (EPS) secara simultan terhadap return saham pada emiten Jakarta Islamic Index tahun 2010 -2013.

\section{LANDASAN TEORI}

Husnan (2009:3) pasar modal adalah pasar untuk berbagai instrumen keuangan jangka panjang yang bisa diperjual-belikan, baik dalam bentuk hutang maupun modal sendiri, baik yang diterbitkan oleh pemerintah, public authorities, maupun perusahaan swasta.

\section{Pasar Modal Syariah}

Pasar modal syariah didefinisikan sebagai pasar modal yang menerapkan prinsip Islam dalam aktivitas bisnis dan tidak memperbolehkan sesuatu yang dilarang dalam hukum Islam seperti riba, maisyir, gharar dan lain-lain. Pasar modal syariah resmi didirikan pada 14 Maret 2003 dengan ditandatanganinya nota kesepahaman antara Bapepam dengan Dewan Syariah Nasional-Majelis Ulama Indonesia (DSN-MUI). Dengan hadirnya indeks tersebut, maka para pemodal telah disediakan sahamsaham yang dapat dijadikan sarana berinvestasi sesuai dengan prinsip syariah.
Jogiyanto (2000:392) informasi yang dipublikasikan sebagai suatu pengumuman akan memberikan signal bagi investor dalam pengambilan keputusan investasi. Jika pengumuman tersebut mengandung nilai positif, maka diharapkan pasar akan bereaksi pada waktu pengumuman tersebut diterima oleh pasar.

\section{Pengertian Jakarta Islamic Index (JII)}

Jakarta Islamic Index adalah salah satu indeks saham yang ada di Indonesia yang menghitung index harga rata-rata saham untuk jenis saham-saham yang memenuhi kriteria syariah. JII telah dikembangkan sejak tanggal 3 Juli 2000. Setiap periodenya, saham yang masuk JII berjumlah 30 (tiga puluh) saham yang memenuhi kriteria syariah. JII menggunakan hari dasar tanggal 1 Januari 1995 dengan nilai dasar 100 (Sutedi, $2011: 65$ ).

\section{Return Saham}

Ang (1997:20) return (kembalian) adalah tingkat keuntungan yang dinikmati oleh pemodal atas suatu investasi yang dilakukannya. Tanpa adanya tingkat keuntungan yang dinikmati dari suatu investasi, tentunya investor (pemodal) tidak akan melakukan investasi. Jadi setiap investasi baik jangka pendek maupun jangka panjang mempunyai tujuan utama mendapatkan keuntungan yang disebut sebagai return saham baik langsung maupun tidak langsung.

\section{investasi Dan Saham Syariah}

\section{A. Signaling Theory}


Investasi merupakan suatu penundaan konsumsi sekarang yang dimasukkan ke dalam proses produksi yang efisien selama periode waktu yang terntentu yang hasilnya untuk konsumsi di masa mendatang (Jogiyanto, 2013:5).

Investasi menurut pandangan Islam, investasi memiliki definisi dan tujuan yang lebih luas karena mencakup aspek dunia (materi) dan akhirat (ukhrawi) seperti yang dijelaskan oleh Ryandono (2009:70):

Investasi yang islami adalah pengorbanan sumber daya pada masa sekarang untuk mendapatkan hasil yang pasti, dengan harapan memperoleh hasil yang lebih besar di masa yang akan datang, baik langsung maupun tidak langsung seraya tetap berpijak pada prinsip-prinsip syariah Islam secara menyeluruh (kaffah).

\section{Analisis Fundamental}

Suatu analisis fundamental merupakan analisis yang digunakan untuk mencoba memprediksi harga saham diwaktu yang akan datang dengan mengestimasi nilai faktor-faktor fundamental yang berpengaruh terhadap harga saham diwaktu yang akan datang dan menerapkan hubungan variabelvariabel tersebut sehingga diperoleh taksiran harga saham. Jika kemampuan perusahaan semakin meningkat (menghasilkan laba yang meningkat) maka harga saham akan meningkat pula. Dengan kata lain profitabilitas akan mempengaruhi harga saham (Husnan, 2009:307). a. Return On Asset (ROA)

ROA digunakan untuk mengetahui kinerja perusahaan berdasarkan kemampuan perusahaan dalam mendayagunakan jumlah assets yang dimiliki (Susilowati dan Turyanto 2011:19).

b. Net Profit Margin (NPM) Susilowati dan Turyanto (2011:24) Net Profit Margin merupakan perbandingan antara laba setelah pajak (EAT) dengan penjualan.

c. Earning Per Share (EPS)

Earning per share merupakan ukuran kemampuan perusahaan dalam menghasilkan keuntungan perlembar saham bagi pemiliknya (Tandelilin, 2001:232).

\section{Hubungan Antar Variabel}

a. Hubungan Return On Assets (ROA) Terhadap Return Saham

Arista (2012:6) Semakin tinggi ROA menunjukkan semakin efektif perusahaan dalam memanfaatkan aktivanya untuk menghasilkan laba bersih setelah pajak. Peningkatan ROA akan menambah daya tarik investor untuk menanamkan dananya dalam perusahaan. Sehingga harga saham perusahaan akan meningkat, dengan kata lain ROA akan berdampak positif terhadap return saham.

b. Hubungan Net Profit Margin (NPM) Terhadap Return Saham 
Semakin tinggi NPM suatu perusahaan berarti semakin baik kinerja perusahaan tersebut dari sudut manajemen. Berita baik berupa peningkatan rasio NPM perusahaan dari tahun ke tahun diharapkan dapat meningkatkan kepercayaan investor terhadap perusahaan. Kepercayaan tersebut akan dapat merubah permintaan atau penawaran harga saham perusahaan yang selanjutnya akan berpengaruh terhadap kenaikan harga saham tersebut (Putri, 2012:31).

c. Hubungan Earning Per Share (EPS) Terhadap Return Saham

EPS yang besar menandakan kemampuan perusahaan yang lebih besar dalam menghasilkan keuntungan bersih dari setiap lembar saham. Kepercayaan investor kepada emiten selalu dibarengi dengan permintaan akan saham emiten. Apabila permintaan saham naik maka harga sahampun meningkat, maka return saham akan meningkat (Hartati, 2010: 27).

\section{Hipotesis}

Berdasarkan tujuan penelitian ini, hipotesis yang digunakan dalam penelitian ini adalah:

$H_{1} \quad$ : Return On Asset (ROA), Net Profit Margin (NPM) dan Earning Per Share (EPS) secara parsial berpengaruh signifikan terhadap return saham perusahaan yang terdaftar dalam Jakarta Islamic Index tahun 2010-2013

$\boldsymbol{H}_{2}$ : Return On Asset (ROA), Net Profit Margin (NPM) dan Earning Per Share (EPS) secara simultan berpengaruh signifikan terhadap return saham perusahaan yang terdaftar dalam Jakarta Islamic Index tahun 2010-2013

\section{METODOLOGI PENELITIAN}

Pendekatan yang digunakan dalam penelitian ini adalah pendekatan kuantitatif. Pendekatan ini dilakukan dengan melakukan pengujian hipotesis, pengukuran data dan pembuatan kesimpulan. Uji statistik yang digunakan dalam analisis ini adalah metode regresi data panel dan data yang diperoleh didapat dari Indonesian Capital Market Directory (ICMD) dan Indonesian Stock Exchange (IDX) dengan periode waktu tahunan 2010 sampai 2013.

\section{Identifikasi Variabel}

Penelitian ini akan menguji lima variabel eksogen dan satu variabel endogen. Variabel yang digunakan dalam penelitian ini, yaitu sebagai berikut:

1. Variabel eksogen $(X)$ dalam penelitian ini adalah Return On Asset (ROA), Net Profit Margin (NPM) dan Earning Per Share (EPS).

2. Variabel endogen ( $Y$ ) dalam penelitian ini adalah return saham emiten yang terdaftar dalam Jakarta Islamic Index (JII) tahun 2010-2013.

\section{Definisi Operasional Variabel}


Dalam penelitian ini terdapat dua variabel utama, yaitu:

1. Variabel independen yaitu Return On Asset (ROA), Net Profit Margin (NPM) dan Earning Per Share (EPS).

2. Variabel dependen yaitu return saham.

a. Variabel Return On Asset (ROA)

Return On Asset (ROA) adalah kemampuan perusahaan dalam menghasilkan laba setelah pajak (EAT) berdasarkan total aset yang dimiliki perusahaan.

b. Variabel Net Profit Margin (NPM)

Net profit margin menunjukkan rupiah laba bersih yang dihasilkan oleh setiap satu rupiah penjualan. Net Profit Margin dapat dihitung dengan membagi laba setelah pajak dengan penjualan (Sudana, 2009:26).

C. Variabel Earning Per Share (EPS)

Earning Per Share adalah jumlah laba yang menjadi hak untuk pemegang saham (Prastowo dan Juliaty, 2002:93).

d. Variabel Return Saham

Konsep return saham dalam penelitian ini adalah harga saham saat ini dikurangi harga saham periode sebelumnya dibanding dengan harga saham periode sebelumnya, tanpa mempertimbangkan yield (dividen). Adapun nilai closing price dalam penelitian ini diambil dari Indonesian Capital Market Directory.

\section{Jenis dan Sumber Data}

Jenis data yang digunakan dalam penelitian ini adalah data sekunder yaitu data yang diperoleh dari Indonesian Capital Market Directory (ICMD), mengakses website www.idx.co.id dan laporan kevangan yang diinformasikan.

\section{Prosedur Pengumpulan Data}

a. Populasi

Populasi dalam penelitian ini adalah seluruh saham-saham syariah yang tercatat dalam Jakarta Islamic Index (JII) di Bursa Efek Indonesia (BEI) selama periode 20102013.

\section{b. Sampel}

Sampel adalah bagian dari populasi, survei sampel adalah suatu prosedur hanya sebagian dari populasi saja yang diambil dan dipergunakan untuk menentukan sifat serta ciri yang dikehendaki dari populasi (Nazir, 2003:271). Berhubung seluruh populasi yang dikriteriakan adalah sampel maka penelitian ini merupakan Census Sampling.

\section{Teknik Analisis}

a. Regresi Data Panel

Regresi dengan menggunakan data panel disebut model regresi data panel. Ada beberapa keuntungan yang diperoleh dengan menggunakan data panel. Pertama, data panel yang merupakan gabungan dua data yaitu time series (selama beberapa tahun tertentu) dan cross section (pada beberapa perusahaan tertentu) yang mampu menyediakan data 
yang lebih banyak sehingga akan menghasilkan degree of freedom yang lebih besar (Gujarati, 2003:636).

b. Estimasi Regresi Data Panel

Estimasi model regresi panel, terdapat 3 pendekatan yang biasa digunakan (Widarjono, 2007:251):

1. Common Effects Model (Pool least square)

2. Fixed Effects Model

3. Random Effects Model (Error Component Model)

c. Uji Asumsi Klasik

1. Uji Normalitas

Ghozali (2006:162) mengatakan bahwa uji normalitas adalah sebuah uji yang digunakan untuk melihat apakah nilai residual terdistribusi normal atau tidak. Nilai regresi yang baik adalah jika memiliki nilai residual yang terdistribusi normal. Jadi, uji normalitas tidak dilakukan pada masing-masing variabel, tetapi pada nilai residualnya.

2. Uji Multikolinearitas

Multikolinearitas merupakan uji asumsi klasik yang menandakan suatu situasi hubungan linear yang hampir sempurna diantara beberapa atau semua variable eksogen yang ada. Suatu model regresi dikatakan baik dan dapat ditarik kesimpulan apabila bebas dari penyimpangan atau bebas dari multikolinearitas, sehingga tidak terdapat korelasi diantara variabel eksogen.

3. Uji Heteroskedastisitas

Uji heteroskedastisitas merupakan sebuah uji keadaan pada nilai variabel endogen tertentu masingmasing kesalahan $\left(e_{i}\right)$ mempunyai nilai varian yang sama besar ơ ${ }^{2}$. Jika dalam model yang dianalisis terjadi heteroskedastisitas, maka nilai-nilai estimator (koefisien regresi) dari model tersebut menjadi tidak efisien meskipun estimator tersebut tidak bias dan konsisten.

\section{Uji Autokorelasi}

Gujarati (2004:442) autokorelasi adalah suatu korelasi antara anggota serangkaian observasi yang diurutkan menurut waktu dan ruang. Gejala yang ditimbulkan oleh autokorelasi ini adalah terdapat korelasi antara varian error atau penggangu pada periode tertentu dengan periode sebelumnya.

d. Alat Uji Hipotesis

a. Uji t-Statistik

Adalah sebuah uji yang digunakan untuk menguji pengaruh variabel eksogen terhadap variabel endogen. Prosedur pengujiannya adalah:

1. Hipotesis statistik yang digunakan $H_{0}: \mu=0$, berarti secara sendiri-sendiri (parsial) variabel eksogen tidak ada pengaruh signifikan terhadap variabel endogen. 
$H_{a}: \mu \neq 0$, berarti secara sendiri-sendiri (parsial) variabel eksogen ada pengaruh signifikan terhadap variabel endogen.

2. Taraf kesalahan yang digunakan adalah $(a)=5 \%$ dengan didasarkan pada $d k=(n-k-1)$.

3. Harga t-hitung dapat dihitung dengan rumus:

$$
t_{\text {hitung }}=\frac{\text { Koefisien Determinasi (bi) }}{\text { Standard Deviasi (se (bi)) }}
$$

Keterangan:

bl=Parameter variabel eksogen

$\mathrm{Sbl}=$ Standar deviasi parameter variabel eksogen

ApabilaThitung $>T_{\text {tabel }}$ atau nilai $\dagger$ yang dihasilkan pada tingkat signifikansi dibawah 0,05 (5\%), berarti pada pengujian ini tidak mampu atau gagal menerima $\mathrm{H}_{0}$ sehingga $\mathrm{Ha}$ diterima. Demikian juga sebaliknya bila Thitung $<T_{\text {tabel }}$ atau nilai t yang dihasilkan pada tingkat signifikansi diatas 0,05 (5\%), maka pengujian tidak mampu menolak $\mathrm{H}_{0}$ sehingga $\mathrm{H}_{0}$ diterima dan $\mathrm{H}_{\mathrm{a}}$ ditolak.

b. Uji F-Statistik

Uji $F$ dilakukan untuk mengetahui signifikansi pengaruh variable bebas terhadap variabel secara simultan, langkah yang diperlukan antara lain (Sudjana, 1996:355) :

1. Perumusan Hipotesis

$H_{0}: \beta_{1}=\beta_{2}=\beta_{3}=\beta_{4}=\beta_{5}=0$, berarti variabel $X_{1}, X_{2}, X_{3}, X_{4}$, dan $X_{5}$ secara bersama-sama berpengaruh tidak secara signifikan terhadap variabel tergantung.
$H_{0}: \beta_{1} \neq \beta_{2} \neq \beta_{3} \neq \beta_{4} \neq \beta_{5} \neq 0$, berarti variabel $X_{1}, X_{2}, X_{3}, X_{4}$, dan $X_{5}$ secara bersama-sama berpengaruh secara signifikan terhadap variabel tergantung.

2. Menentukan besarnya $\mathrm{F}$ hitung dengan rumus:

$$
F=\frac{R^{2} / k}{\left(1-R^{2}\right) /(n-k-1)}
$$

3. Pengambilan Keputusan Jika Probabilitas $>0,05$ (level of significant $5 \%$ ) dan $\mathrm{F}_{\text {hitung }}<\mathrm{F}$ tabel (df $\mathrm{V} 1=\mathrm{k}$ dan $\mathrm{V} 2=$ $n-k-1$ dan $a=5 \%$ ) maka Ho diterima, sedangkan jika probabilitas $<0,05$ dan $\mathrm{F}$ hitung $>\mathrm{F}$ tabel maka $\mathrm{H}_{0}$ ditolak.

C. Uji $R^{2}$ (R-square)

Pengujian ini dilakukan untuk mengukur seberapa besar persentase variabel dependen dapat dijelaskan oleh variabel independennya dengan melihat nilai $R^{2} \quad$ (R-square) dari hasil estimasi. Nilai $R^{2}$ berkisar antara $0-1$. Jika $R^{2}$ sama dengan 1, maka garis regresi yang digunakan mampu menjelaskan 100 persen variasi variabel dependen. Namun jika $R^{2}$ sama dengan 0 berarti variabel independen tidak dapat menjelaskan sedikitpun variasi variabel dependennya.

\section{HASIL DAN PEMBAHASAN}

Jakarta Islamic Index (JII) diterbitkan oleh Bursa Efek Indonesia (BEI) pada tanggal 3 Juli 2000 atas kerja sama dengan PT. Danareksa Investment Management.

\begin{tabular}{|l|c|c|c|c|}
\hline & $\begin{array}{l}\text { RETURN } \\
\text { SAHAM }\end{array}$ & ROA & NPM & EPS \\
\hline Mean & 0.061541 & 19.59125 & 19.77042 & 1007.933 \\
\hline Median & 0.071999 & 18.47500 & 20.45000 & 774.9000 \\
\hline Maximum & 1.500000 & 71.51000 & 36.31000 & 4393.140 \\
\hline Minimum & -0.897297 & 3.680000 & 9.410000 & 24.29000 \\
\hline
\end{tabular}


Jakarta Islamic Index diterbitkan untuk menjadi tolak ukur (benchmark) kinerja saham-saham syariah yang terdapat di BEl. Selain itu, penerbitan indeks saham syariah ini juga bertujuan untuk mempermudah para investor muslim dalam melakukan investasi di bursa efek tanpa melanggar prinsip-prinsip syariah Islam. Jakarta Islamic Index terdiri dari 30 saham syariah yang komponennya diperbarui setiap enam bulan sekali, yaitu pada bulan Juni dan Desember.

Penelitian ini menggunakan Jakarta Islamic Index (JII) sebagai subjek penelitian. Berikut adalah emiten JII yang terdaftar berturut-turut pada tahun 2010-2013 yang bersumber dari www.idx.co.id. Lampiran 1

Tabel 2.

Perusahaan yang terdaftar di JII

\begin{tabular}{|l|l|c|}
\hline No & Nama Emiten & Kode \\
\hline 1 & PT Astra Agro Lestari, Tbk & AALI \\
\hline 2 & PT Astra Internasional, Tbk & ASII \\
\hline 3 & PT Indocement Tunggal Prakarsa, Tbk & INTP \\
\hline 4 & PT Indo Tambangraya Megah, Tbk & ITMG \\
\hline 5 & PT Kalbe Farma, Tbk & KLBF \\
\hline 6 & PT Lippo Karawaci, Tbk & LPKR \\
\hline 8 & $\begin{array}{l}\text { PT PP London Sumatra Indonesia, Tbk } \\
\text { (Persero), Tbk }\end{array}$ & LSIP \\
\hline 9 & PT Semen Indonesia (Persero), Tbk & PTBA \\
\hline 10 & $\begin{array}{l}\text { PT Telekomunikasi Indonesia (Persero), } \\
\text { Tbk }\end{array}$ & TLKM \\
\hline 11 & PT United Tractors, Tbk & UNTR \\
\hline 12 & PT Unilever Indonesia, Tbk & UNVR \\
\hline
\end{tabular}

Sumber : Data diolah (IDX)

\section{Deskripsi Hasil Penelitian}

Tabel 3.

Output Eviews 6.0 Deskripsi Data Return Saham dan Rasio Profitabilitas
Sumber: Data diolah

Berdasarkan Tabel 3. nilai tertinggi dan terendah dari variabel ROA, NPM dan EPS dapat dikatakan terpaut sangat jauh sehingga menunjukkan bahwa return saham para emiten yang terdaftar dalam Jakarta Islamic Index (JII) tahun 2010-2013 mengalami pergerakan yang tidak menentu setiap tahunnya. Range dapat dikatakan lebar yang mengakibatkan varians data besar. Return nilai tertinggi sebesar 1.5, nilai terendahnya sebesar 0.897 dan nilai rata-ratanya sebesar 0.062 . Return On Assets (ROA) memiliki nilai tertinggi sebesar 71.51, nilai terendahnya sebesar 3.68 dan nilai rata-ratanya sebesar 19.59. Net Profit Margin (NPM) memiliki nilai tertinggi sebesar 36.31, nilai terendahnya sebesar 9.41 dan nilai rata-ratanya sebesar 19.77. Earning Per Share (EPS) memiliki nilai tertinggi sebesar 4393.14, nilai terendahnya sebesar 24.29 dan nilai rata-ratanya sebesar 1007.93.

\section{Pemodelan Return Saham}

Tabel 4. Hasil Perhitungan Uji Chow

\begin{tabular}{|l|l|}
\hline & Nilai \\
\hline Fhitung & 0,7117 \\
\hline$p$-value & 0,7188 \\
\hline$A$ & 0,05 \\
\hline
\end{tabular}

Sumber: Data diolah

Hasil perhitungan uji chow diperoleh nilai Fhitung sebesar 0,7188 yang lebih besar dari $a=0,05$ sehingga dapat disimpulkan bahwa tidak terdapat efek individu pada model persamaan return saham para 
emiten Jakarta Islamic Index (JII) dengan kata lain dan tidak perlu dilakukan pengujian Hausman.

Tabel 5.

Hasil Estimasi Model CEM

\begin{tabular}{|lllll|}
\hline Var. & Coeff. & Std. Error & t-Statistic & Prob. \\
\hline \hline C & 0.176293 & 0.224398 & 0.785626 & 0.4363 \\
ROA? & 0.002752 & 0.005542 & 0.496682 & 0.6219 \\
NPM? & -0.009771 & 0.009734 & -1.003826 & 0.3210 \\
EPS? & $2.43 \mathrm{E}-05$ & $6.00 \mathrm{E}-05$ & 0.404898 & 0.6875 \\
\hline \hline R-squared & 0.033154 & Mean dependent var 0.061541 \\
Adjusted R- & & & & \\
squared & -0.032767 & S.D. dependent var & 0.412116 \\
S.E. of regression & 0.418814 & Akaike info criterion & 1.176875 \\
Sum squared & & & \\
resid & 7.717820 & Schwarz criterion & 1.332808 \\
Log likelihood & -24.24499 & Hannan-Quinn criter. & 1.235802 \\
F-statistic & 0.502931 & Durbin-Watson stat & 2.080154 \\
Prob(F-statistic) & 0.682235 & & \\
\hline \hline
\end{tabular}

Sumber: Data diolah

Hasil output diatas menunjukkan bahwa secara serentak melalui nilai probability statistik uji F sebesar 0,6822 lebih besar dari $a=0,05$ sehingga dapat disimpulkan bahwa secara serentak rasio profitabilitas berpengaruh tidak signifikan terhadap return saham para emiten Jakarta Islamic Index (JII).

\section{Uji Asumsi Klasik}

1. Uji Normalitas

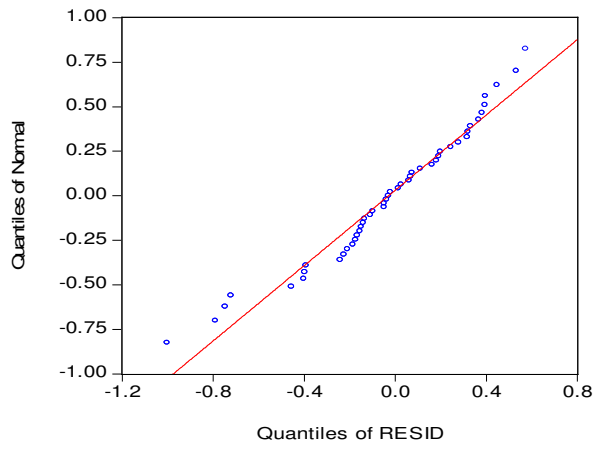

Sumber: Data diolah Gambar 1.

Hasil Uji Normalitas - Normal Probability Plot

Hasil output Eviews 6.0 diatas menunjukkan bahwa data menyebar disekitar garis diagonal dan mengikuti arah garis diagonal. Kesimpulan dari hasil Normal Probability Plot diatas adalah model regresi memenuhi asumsi normalitas.

\section{Uji Multikolinearitas}

Tabel 6.

Hasil Uji Normalitas - Matriks Korelasi antar Variabel Independen

\begin{tabular}{|c|c|c|c|}
\hline & ROA & NPM & EPS \\
\hline ROA & 1 & 0.1511 & 0.1464 \\
\hline NPM & 0.1511 & 1 & -0.1347 \\
\hline EPS & 0.1464 & -0.1347 & 1 \\
\hline \multicolumn{4}{|c|}{ Sumber: Data diolah }
\end{tabular}

Berdasarkan hasil output di atas dapat diketahui bahwa nilai korelasi antar variabel bebasnya dapat dikatakan sangat rendah. Sehingga dapat disimpulkan bahwa antara variabel bebas tidak terdapat multikolinearitas. Dengan demikian, data panel dalam penelitian ini telah terbebas dari masalah multikolinearitas.

\section{Uji Heteroskedastisitas}


Uji heteroskedastisitas ini dilakukan dengan menggunakan White Heteroscedasticity untuk mengetahui apakah terdapat unsur heteroskedastisitas pada model yang dipilih. Hipotesis uji White adalah

\section{$\mathrm{H}_{0}$ : Tidak terdapat unsur heteroskedastisitas}

$\mathrm{H}_{1}$ : Terdapat unsur heteroskedastisitas

Berdasarkan uji, diperoleh nilai probabilitas dari uji White sebesar 0,1562 yang lebih besar dari $a=0,05$ sehingga menghasilkan keputusan $\mathrm{H}_{0}$ diterima atau dapat disimpulkan bahwa dengan tingkat keyakinan 95 persen, data tidak mengandung unsur heteroskedastisitas.

\section{Uji Autokorelasi}

Uji autokorelasi dalam penelitian ini menggunakan statistik uji Durbin Watson (DW-Stat) pada data yang telah berdistribusi normal. Perhitungan uji Durbin Watson menghasilkan nilai statistik uji sebesar 2,080 dengan k (banyak parameter tanpa intersep) $=3, n$ (banyak data) $=48$, maka berdasarkan tabel durbin watson diperoleh $d_{L}=1,3619$ dan $d_{u}=1.7206$, sehingga diperoleh daerah keputusan du $(1,7206)<d(2,080)<4-d_{u}(2,2794)$ yakni $H_{0}$ diterima (tidak ada autokorelasi).

\section{Uji Hipotesis}

1. Uji t-statistik

Tabel 7.

Hasil Estimasi Model memenuhi Asumsi

BLUE

\begin{tabular}{|c|c|c|}
\hline Variable & t-Statistic & Prob. \\
\hline C & 0.785626 & 0.4363 \\
\hline
\end{tabular}

\begin{tabular}{|c|c|c|}
\hline ROA & 0.496682 & 0.6219 \\
\hline NPM & -1.003826 & 0.3210 \\
\hline EPS & 0.404898 & 0.6875 \\
\hline
\end{tabular}

Sumber: Data diolah

1) Variabel Return On Assets (ROA) memiliki thitung sebesar 0.496 dengan probability sebesar 0.621 . Sedangkan tabel dengan nilai probability sebesar 0,05 adalah 2.014, maka thitung $<t_{\text {tabel }}(0.496<2.014)$ dan nilai probability lebih besar daripada 0,05 . Dapat disimpulkan bahwa ROA berpengaruh tidak signifikan secara parsial terhadap return saham.

2) Variabel Net Profit Margin (NPM) memiliki thitung sebesar -1.00 dengan probability sebesar 0.321 . Sedangkan tabel dengan nilai probability sebesar 0,05 adalah 2.014, maka thitung $<t_{\text {tabel }}(-1.00<2.014)$ dan nilai probability lebih besar daripada 0,05 . Dapat disimpulkan bahwa NPM berpengaruh tidak signifikan secara parsial terhadap return saham.

3) Variabel Earning Per Share (EPS) memiliki thitung sebesar 0.404 dengan probability sebesar 0.687. Sedangkan tabel dengan nilai probability sebesar 0,05 adalah 2.014, maka thitung $<t_{\text {tabel }}(0.404<2.014)$ dan nilai probability lebih besar daripada 0,05 . Dapat disimpulkan bahwa EPS berpengaruh tidak signifikan secara parsial terhadap return saham.

\section{Uji F-Statistik}

Tabel 8.

Hasil Uji Statistik F

\begin{tabular}{|l|l|}
\multicolumn{1}{c}{ Hasil Uji Statistik F } \\
\hline F-statistic & 0.502931 \\
\hline Prob(F-statistic) & 0.682235 \\
\hline
\end{tabular}

Sumber: Data diolah 
Hasil output diatas menunjukkan bahwa nilai statistik uji $F$ 0,5029 kurang dari nilai $F$ tabel 2,8164 dan nilai probabilitas $F$ yang dihasilkan pada tingkat signifikansi yakni 0,6822 yang lebih dari $a=0,05(5 \%)$, artinya pada pengujian ini dapat disimpulkan bahwa variabel ROA, NPM, dan EPS secara serentak berpengaruh tidak signifikan terhadap return saham para emiten Jakarta Islamic Index (JII).

\section{Uji $R$ 2 ( $R$-square)}

Pengujian ini dilakukan untuk mengukur seberapa besar persentase variabel dependen dapat dijelaskan oleh variabel independennya dengan melihat nilai $R 2$ (R-square) dari hasil estimasi. Dari hasil regresi diperoleh nilai koefisien determinasi ( $R$ square) $=0,033$. Ini artinya $3,3 \%$ perubahan return saham para emiten Jakarta Islamic Index (JII) dapat dijelaskan atau dipengaruhi oleh ROA, NPM, dan EPS secara bersama-sama. Sedangkan 96,7\% dipengaruhi oleh variabel lain yang tidak termasuk dalam penelitian ini.

\section{Pembahasan}

a. Pengaruh Return On Asset (ROA) terhadap Return Saham

Dalam penelitian ini variabel ROA memiliki nilai thitung sebesar 0.496682 dengan nilai probability sebesar 0.6219, maka dari hasil tersebut dapat disimpulkan bahwa nilai probability lebih besar dari tingkat probability yang telah ditentukan yaitu 0.05. Sedangkan tabel menunjukkan angka 2.014, maka thitung < tabel $(0.496682<2.014)$. Hasil tersebut menunjukkan bahwa nilai ROA berpengaruh tidak signifikan terhadap return saham.

b. Pengaruh Net Profit Margin (NPM) terhadap Return Saham

Dalam penelitian ini variabel NPM memiliki nilai thitung sebesar -1.003826 dengan nilai probability sebesar 0.3210 , maka dari hasil tersebut dapat disimpulkan bahwa nilai signifikansi lebih besar dari tingkat signifikan yang telah ditentukan yaitu 0.05 . Sedangkan tabel menunjukkan angka 2.014, maka thitung $<t_{\text {tabel }}(-1.003826<2.014)$. Hasil tersebut menunjukkan bahwa nilai NPM berpengaruh tidak signifikan terhadap return saham.

c. Pengaruh Earning Per Share (EPS) terhadap Return Saham

Dalam penelitian ini variabel EPS memiliki nilai thitung sebesar 0.404898 dengan nilai probability sebesar 0.6875 , maka dari hasil tersebut dapat disimpulkan bahwa nilai probability lebih kecil dari tingkat probability yang telah ditentukan yaitu 0.05 . Sedangkan tabel menunjukkan angka 2.014, maka thitung $>t_{\text {tabel }}(0.404898>2.014)$. Hasil tersebut menunjukkan bahwa nilai EPS berpengaruh signifikan terhadap return saham.

d. Pengaruh Return On Asset (ROA) dan Net Profit Margin (NPM) Dan Earning Per Share (EPS) terhadap Return Saham Secara Simultan

Dalam penelitian ini variabel Return On Asset (ROA), Net Profit Margin (NPM) dan 
Earning Per Share (EPS) menunjukkan nilai probability sebesar 0.682235 terhadap return saham. Hal ini menunjukkan bahwa ROA, NPM dan EPS berpengaruh tidak signifikan terhadap return saham secara bersama-sama atau simultan.

Dari hasil regresi diperoleh nilai koefisien determinasi ( $R$ square) $=0,033$. Ini artinya 3,3\% perubahan return saham para emiten Jakarta Islamic Index (JII) dapat dijelaskan atau dipengaruhi oleh ROA, NPM, dan EPS secara bersama-sama. Sedangkan $96,7 \%$ dipengaruhi oleh variabel lain yang tidak termasuk dalam penelitian ini.

Surat Al-Luaman ayat 34 sebagai berikut (Ryandono,2009:91):

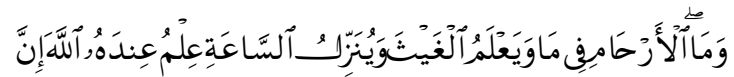

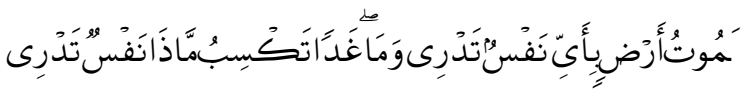

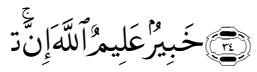

"innallaaha 'indahu 'ilmu ssaa'ati wayunazzilu Ighaytsa waya'lamu maa fii 1 arhaami wamaa tadrii nafsun maatsaa taksibu ghadan wamaa tadrii nafsn bi-ayyi ardhin tamuutu innallaaha "aliimun khabiir" Artinya: Sesungguhnya Allah, hanya pada sisi-Nya sajalah pengetahuan tentang hari Kiamat; dan Dia-lah yang menurunkan hujan, dan mengetahui apa yang ada dalam Rahim. dan tiada seorangpun yang dapat mengetahui (dengan pasti) apa yang akan diusahakannya besok. dan tiada seorangpun yang dapat mengetahui di bumi mana Dia akan mati. Sesungguhnya Allah Maha mengetahui lagi Maha Mengenal. (QS. Al-Luqman:34) (Departemen Agama, 2012:813)
Jadi dalam ayat tersebut tersirat pesan yaitu ketidakpastian merupakan sunnatullah yang dihadapi manusia namun kita sebagai manusia juga harus bekerja mencari rezeki dari kemurahan Allah. Bersama dengan itu, kita senantiasa ingat kepada-Nya. Artinya kita sebagai manusia hanya berusaha dan berdoa, hasilnya Allah yang menentukan. Sama halnya dengan investasi dalam pasar modal, kita sebagai investor melakukan berbagai usaha salah satunya dengan menganalisis laporan keuangan perusahaan, mencari informasi baik fundamental maupun teknikal tetapi hal tersebut tidak mengalihkan resiko yang akan kita terima karena risiko merupakan bagian dari takdir seperti yang dijelaskan surat At-Taghabun 64:1 1 berikut:

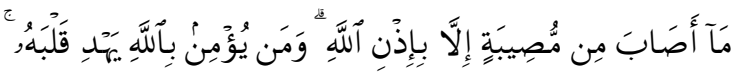

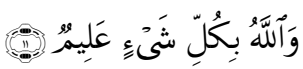

"Maa ashaaba mim mushiibatin illaa bi idznillaahi wa may yu'mim billaahi yahdi qalbahuu wallaahu bi kulli sayi-in 'aliim"

Artinya: Tidak ada suatu musibah pun yang menimpa seseorang kecuali dengan ijin Allah; dan barang siapa yang beriman kepada Allah niscaya Dia akan memberi petunjuk kepada hatinya dan Allah Maha mengetahui segala.

(QS. At-Taghaabun:11) (Departemen Agama, 2012:1136)

\section{Temuan}

Karakteristik sebagian besar investor Indonesia akan turut menentukan faktor apa yang berperan penting dalam proses pengambilan keputusan. Dalam penelitian 
ini perilaku investor di pasar modal cenderung kurang memperhatikan laporan keuangan perusahaan atau kurang tertarik dengan analisis fundamental khususnya investor yang menanamkan modalnya di perusahaan yang terdaftar dalam Jakarta Islamic Index (JII). Hal ini dapat dilihat dari hasil penelitian yang memiliki koefisien determinasi ( $R$ square) $=0,033$. Artinya $3,3 \%$ perubahan return saham para emiten Jakarta Islamic Index (JII) dapat dijelaskan atau dipengaruhi oleh ROA, NPM dan EPS secara bersama-sama Sedangkan 96,7\% dipengaruhi oleh variabel lain yang tidak termasuk dalam penelitian ini. Variabel lain yang mempengaruhi return saham selain konsep yang telah dikemukakan oleh Alwi, Weston dan Brigham, menurut peneliti ada faktor lain yang mempengaruhi return saham perusahaan yang terdaftar dalam Jakarta Islamic Index (JII) yaitu analisis teknikal dan emosional religi.

(Van Eyde, 1996 dalam Lawrence, 1997) sekitar $90 \%$ dari pialang saham menggunakan analisis teknikal. Keunggulan analisis teknikal ini adalah bahwa mampu memperoleh informasi lebih cepat, sehingga dengan kemampuan para analis dan daya insting yang tajam akan bisa secara langsung menerjemahkannya dalam tindakan menjual dan membeli saham guna memperoleh keuntungan (Taswan dan Soliha, 2002).

Dapat dikatakan variabel lain yang mempengaruhi return saham pada emiten yang terdaftar di Jakarta Islamic Index (JII) tahun 2010-2013 adalah perilaku investor di pasar modal yang cenderung menggunakan analisis teknikal dibandingkan analisis fundamental karena investor di pasar modal kurang memperhatikan laporan keuangan perusahaan tetapi lebih melihat grafik atau volume perdagangan yang lebih mudah dipahami.

Seiring dengan meningkatnya rasa keberagamaan (religiusitas) masyarakat muslim menjalankan syariah Islam dalam kehidupan sosial-ekonomi, semakin banyak institusi bisnis Islami yang menjalankan kegiatan operasional dan usahanya berlandaskan prinsip syariah. Dalam rangka merespon segala hal yang berhubungan dengan investasi syariah sebagai akibat pesatnya perkembangan ekonomi syariah di seluruh dunia, di Jakarta dibentuk Jakarta Islamic Index (JII) yang dikeluarkan oleh PT Bursa Efek Jakarta pada tanggal 3 Juli 2000. Perusahaan-perusahaan (emiten) yang kegiatan utamanya tidak sesuai dengan syariah maka akan dikeluarkan dari kelompok JII (Sutedi, 2011:30).

\section{SIMPULAN}

Berdasarkan hasil penelitian dan pembahasan yang telah dilakukan mengenai hubungan antara variabel Return On Asset (ROA), Net Profit Margin (NPM) dan Earning Per Share (EPS) terhadap return saham, maka simpulan yang dapat diambil adalah: 
1. Variabel Return On Asset (ROA) berpengaruh tidak signifikan secara parsial terhadap return saham perusahaan yang terdaftar di Jakarta Islamic Index (JII) tahun 2010-2013.

2. Variabel Net Profit Margin (NPM) berpengaruh tidak signifikan secara parsial terhadap return saham perusahaan yang terdaftar di Jakarta Islamic Index (JII) tahun 2010-2013.

3. Variabel Earning Per Share (EPS) berpengaruh tidak signifikan secara parsial terhadap return saham perusahaan yang terdaftar di Jakarta Islamic Index (JII) tahun 2010-2013.

4. Variabel ROA, NPM dan EPS berpengaruh tidak signifikan secara simultan terhadap return saham perusahaan yang terdaftar di Jakarta Islamic Index (JII) tahun 2010-2013.

\section{DAFTAR PUSTAKA}

Ang, Robert. 1997. Buku Pintar Pasar Modal Indonesia. Jakarta : Media Staff Indonesia.

Anoraga, Pandji dan Piji Pakarti. 2008. Pengantar Pasar Modal. Jakarta. : PT. Rineka Cipta.

Arista. Desy. 2012. Analisis Faktor - Faktor Yang Mempengaruhi Return Saham: Kasus pada Perusahaan Manufaktur yang Go Public di BEl periode tahun 2005
- 2009. Jurnal IImu Manajemen dan Akuntansi Terapan, Vol 3 Nomor 1, Mei 2012.

Ghozali, Imam. 2006. Aplikasi Analisis Multivariate dengan Program SPSS. Semarang: BP UNDIP.

Gujarati, Damodar N. 2003. Basic Econometrics. McGraw-Hill.

Hartati. 2010. Pengaruh Return On Asset (ROA), Debt To Equity Ratio (DER), Earning Per Share (EPS), Price Earning Ratio (PER) Terhadap Return Saham (Studi Pada Perusahaan Manufaktur Yang Terdaftar Di Bursa Efek Indonesia). Surakarta: Universitas Sebelas Maret.

Husnan, Suad \& Enny, Pudjiastuti. 2006," Dasar-dasar Manajemen Kevangan", Edisi Lima, Yogyakarta : UPP STIM YKPN.

Jogiyanto, S.H. 2013. Teori Portofolio Dan Analisis Investasi. Edisi Ketujuh. Yogyakarta: BPFE-YOGYAKARTA.

Nazir, M. 2003. Metode Penelitian. Jakarta: Ghalia Indonesia.

Penman,S.H . 1991. Financial Statement Analysis and Security Valuation. McGrawHill, Singapore.

Prastowo, Dwi \& Yuliaty, Rifky. 2005. "Analisis Laporan Kevangan Konsep dan Aplikasi". Yogyakarta: UPP AMP YKPN.

Putri, Bahar. 2012. Analisis Pengaruh ROA, EPS, NPM, DER, Dan PBV Terhadap Return Saham IStudi Kasus Pada Industri Real Estate And Properti Yang Terdaftar Di Bursa Efek Indonesia Periode 2007-2009). Semarang : Universitas Diponegoro. 
Ryandono, Muhamad Nafik H. 2009. Bursa Efek dan Investasi Syariah. Jakarta: Serambi.

Susilowati, Yeye dan Tri Turyanto. 2011. Reaksi Signal Rasio Profitabilitas Dan Rasio Solvabilitas Terhadap Return Saham Perusahaan. Jurnal Dinamika Keuangan dan Perbankan. Vol.3 No.1 Mei 2011,Hal: 17-37. ISSN: 1979-4878.

Sutedi, Adrian. 2011. Pasar Modal Syariah. Jakarta: Sinar Grafika.

Tandelilin, Eduardus. 2001. Portofolio dan Investasi Teori dan Aplikasi. Yogyakarta: Kanisius.

Widarjono, Agus. 2007. Ekonometrika: Teori dan Aplikasi Untuk Ekonomi dan Bisnis. Edisi Kedua. Yogyakarta: Fakultas konomi UII 